\title{
Intraseasonal Variability over Tropical Africa during Northern Summer
}

\author{
AdRian J. MATTHEWS \\ Schools of Environmental Sciences and Mathematics, University of East Anglia, Norwich, United Kingdom
}

(Manuscript received 30 December 2002, in final form 22 December 2003)

\section{ABSTRACT}

\begin{abstract}
The intraseasonal variability over Africa during northern summer was analyzed, using 25 years of NCEPNCAR reanalysis and satellite data. The dominant pattern of variability was one of enhanced deep convection over the whole African monsoon region. It appeared to arise at least partly as a remote response to the intraseasonal (Madden-Julian) oscillation over the warm pool sector. Twenty days prior to the maximum in convection over Africa, there was no signal over Africa but convection was reduced over the equatorial warm pool. An equatorial Kelvin wave response to this change in warm pool convection propagated eastward and an equatorial Rossby wave response propagated westward and between them they completed a circuit of the equator and met up 20 days later over Africa, where the negative midtropospheric temperature anomalies in the Kelvin and Rossby waves favored deep convection. Over West Africa, the Kelvin wave component contained lower-tropospheric westerly anomalies that acted to increase the boundary layer monsoon flow and moisture supply. The westerly anomalies also increased the cyclonic shear on the equatorward flank of the African easterly jet, leading to enhanced African easterly wave and transient convective activity, which then contributed to the enhanced convection over Africa on the longer intraseasonal time scale. The implications of this intraseasonal mode for predictability over Africa are discussed.
\end{abstract}

\section{Introduction}

Rainfall over West Africa during the summer monsoon season is largely associated with mesoscale convective systems (MCSs; Le Barbé and Lebel 1997; Redelsperger et al. 2002; Diongue et al. 2002) that are often embedded in the northerly flow ahead of the trough in African easterly waves (Burpee 1972; Reed et al. 1977). The African easterly waves themselves arise partly through barotropic and baroclinic instabilities of the low-level African easterly jet (Burpee 1972; Thorncroft and Hoskins 1994a,b; Thorncroft 1995), and appear to fall into two distinct frequency bands with periods from 3 to 5 days and 6 to 9 days (Diedhiou et al. 1999). In turn, the existence and strength of the African easterly jet depends on the poleward surface temperature and soil moisture gradients and surface fluxes of heat and moisture together with the shallow dry convection over the Sahara and the deep moist convection farther south (Thorncroft and Blackburn 1999; Cook 1999).

West African rainfall is highly variable on interannual and decadal time scales and is highly correlated with global sea surface temperature (SST) variability, with dry conditions over the Sahel and wet conditions over Guinea being associated with positive El Niño-Southern

Corresponding author address: Dr. Adrian Matthews, School of Environmental Sciences, University of East Anglia, Norwich NR4 7TJ, United Kingdom.

E-mail:a.j.matthews@uea.ac.uk
Oscillation (ENSO) SST anomalies over the eastern tropical Pacific, positive SST anomalies over the Southern Hemisphere Atlantic, negative anomalies over the Northern Hemisphere Atlantic (the Atlantic dipole), and positive SST anomalies in the tropical Indian Ocean (Folland et al. 1986; Janicot et al. 1998; Rowell 2001). These SST anomalies induce changes in the deep convective regions and an anomalous equatorial wave response that leads to large-scale atmospheric circulation and rainfall changes over the West African region (Rowell et al. 1995; Janicot et al. 1998). The response to ENSO SST anomalies over the eastern tropical Pacific comprises a direct response through changes to the global atmospheric circulation and an indirect response through modification of Atlantic SST anomalies, which then cause further changes in the large-scale circulation (Rowell 2001) with enhanced trade winds over the Atlantic region and weaker monsoonal flow over West Africa leading to dry conditions over the Sahel. However, the link between ENSO and Sahel rainfall has changed over the decades, indicating that decadal SST modes also play a role (Janicot et al. 2001). SST variability appears to be the primary cause of interannual variability in Sahel rainfall, but changes in soil moisture gradients are also important (Rowell et al. 1995) although the two are related (Cook 1999). SST variability over the Mediterranean Sea can also influence Sahel rainfall, with positive Mediterranean SST and evaporation anomalies leading to an increase in the southward 
moisture advection over the Sahara and increased rainfall over the Sahel (Rowell 2003). The anomalies in the large-scale circulation also change the vertical wind shear and the strength, position, and instability of the African easterly jet, which in turn leads to changes in interannual African easterly wave activity and Sahel rainfall (Thorncroft and Rowell 1998).

There is also substantial intraseasonal variability over West Africa, although this appears to be independent of SST variability (Rowell et al. 1995), at least on the month to month time scale. Wavelet analysis of Sahel rainfall revealed two statistically significant spectral peaks, centered on periods of 15 and 40 days (Janicot and Sultan 2001). The 15-day mode was clearly separated from the higher frequency African easterly waves, and the enhanced rainfall was located within the lowlevel trough of a westward-propagating atmospheric wave with a larger horizontal scale than the African easterly waves (Janicot and Sultan 2001; Kiladis and Weickmann 1997). The start of the West African monsoon was also linked with intraseasonal variability; the onset of rainfall was abrupt and synchronous over the whole region (Le Barbé et al. 2002) and was associated with a westward-traveling monsoon depression with a period of 15-40 days (Sultan and Janicot 2000; Grodsky and Carton 2001). There are also intraseasonal teleconnections between West and East Africa; intraseasonal low-level westerly anomalies advect moisture from the West African monsoon region leading to an increase in rainfall over western Kenya and a decrease over eastern Kenya (Camberlin 1996).

On a global scale, the dominant mode of intraseasonal variability is the Madden-Julian oscillation (MJO; Madden and Julian 1994). This is characterized by eastwardpropagating convective and SST anomalies over the warm pool sector and associated global circulation anomalies, with one complete cycle lasting between approximately 30 and 60 days (e.g., Knutson and Weickmann 1987; Rui and Wang 1990; Hendon and Salby 1994; Matthews 2000). During northern summer, the MJO interacts strongly with the Asian monsoon. In addition to the eastward propagation, the convective anomalies propagate northward from the equatorial Indian Ocean to the Tibetan foothills (Yasunari 1981) and are associated with northward-propagating circulation anomalies and active-break cycles in the monsoon (Krishnamurti and Subrahmanyam 1982).

The mechanisms behind the eastward and northward propagation of the MJO convective anomalies are still open to debate. The eastward propagation may be due to complex interactions between equatorial Rossby and Kelvin waves forced by the anomalous convection with the intraseasonal SST anomalies that are generated by the anomalous latent heat flux and surface solar radiative flux anomalies associated with convectively coupled equatorial waves (e.g., Flatau et al. 1997; Woolnough et al. 2000; Shinoda and Hendon 2001; Inness and Slingo 2003). Anomalous moisture convergence due to the boundary layer frictional convergence in the atmospheric Kelvin wave may also favor the eastward propagation of the convective anomalies (Hendon and Salby 1994). The Kelvin wave component propagates eastward and completes a circuit of the equator in 30-60 days, and may initiate the next MJO event (Matthews 2000).

The northward propagation of the convective anomalies may be due to air-sea interactions within the equatorial Rossby wave component of the MJO. Surface frictional convergence into the off-equatorial low pressure center of the equatorial Rossby wave may lead to the initial poleward migration of the anomalous band of convection along the equator (Kemball-Cooke and Wang 2001; Lawrence and Webster 2002). Positive SST anomalies are then generated ahead of the enhanced convection and may then favor its continued northward propagation (Sengupta et al. 2001). Therefore, the intraseasonal variability of the Asian monsoon system appears to be controlled by ocean-atmosphere processes; land-surface interactions do not appear to be important (Ferranti et al. 1999). The spatial patterns of the intraseasonal modes of variability are very similar to those for interannual variability (Sperber et al. 2000). However, the magnitude of intraseasonal activity of the Asian monsoon is not correlated with ENSO or any other interannual SST variability (Lawrence and Webster 2001).

On a larger scale, the effect of the MJO and intraseasonal variability of the Asian monsoon on Africa is not clear. Knutson et al. (1986) and Murakami et al. (1986) both documented eastward- and northward-propagating satellite-measured outgoing longwave radiation (OLR; a proxy for deep tropical convection) anomalies over the Indian Ocean-western Pacific sector with time periods in the 30-60-day range, but found no signal over Africa. However, Knutson and Weickmann (1987) and Annamalai and Slingo (2001) did find a weak convective signal over Africa in their northern summer MJO life cycles such that enhanced convection over Africa coincided with enhanced convection over the equatorial Indian Ocean.

This paper examines further the intraseasonal variability of the African northern summer monsoon in a global context with an emphasis on the mechanisms behind the variability. The data and methodology are described in section 2 , and the relevant aspects of the mean climate of the monsoon are shown in section 3 . In section 4 the local modes of intraseasonal variability over Africa are determined and these are put in a global context in section 5. Finally, conclusions are presented in section 6 .

\section{Data and methodology}

OLR satellite data were used as a proxy for deep tropical convection. The OLR was obtained as daily mean data interpolated onto $2.5^{\circ} \times 2.5^{\circ}$ gridded maps (Liebmann and Smith 1996) for the period 1974 to 2000, with missing data in 1978. National Centers for Envi- 
ronmental Prediction-National Center for Atmospheric Research (NCEP-NCAR) reanalysis wind and geopotential height data (Kalnay et al. 1996) and Microwave Sounding Unit (MSU) temperature data (Spencer et al. 1990) were also obtained at the same time and spatial resolution, and the Reynolds SST data (Reynolds and Smith 1994) were used from 1982 to 1999. Previous studies have found the NCEP-NCAR reanalysis does capture variability over West Africa, in particular African easterly waves (Diedhiou et al. 1999, 2001) and interannual variability of the West African monsoon (Janicot et al. 2001), and also intraseasonal variability of the Asian monsoon (Annamalai et al. 1999).

The data were analyzed for the July-September (JAS) West African summer monsoon season, 25 summers in total. To isolate the intraseasonal variability, the seasonal cycle (first 12 annual harmonics) was removed and the data were passed through a 241-weight 20-200day bandpass Lanczos filter (Duchon 1979), identical to that used in Matthews (2000). This filter has a much broader bandpass than the typically 30-70-day variability associated with the MJO. Empirical orthogonal function (EOF) analysis was used to determine the main modes of variability. Lagged regression maps of other variables were then constructed using the principal component (PC) time series as the dependent variable. The EOF and regression analyses as applied here are described in more detail in Matthews (2000). The analysis was repeated with an even broader 10-200-day filter and the results were very similar.

\section{Climatology of the African summer monsoon}

Some aspects of the mean climate over the African region are discussed here so that the anomalies shown later can be put into context. The southeasterly lowertropospheric trade winds in the tropical South Atlantic cross the equator and are deflected to the right by the changing Coriolis force to become the southwesterly monsoon flow over Africa between approximately $5^{\circ}$ and $15^{\circ} \mathrm{N}$ (Fig. 1a). These southwesterly winds also form the equatorward part of a cyclonic circulation around the Saharan heat low. These monsoon winds advect moisture from the Atlantic, which feeds the deep moist convection in this region, indicated by the mean OLR values below $210 \mathrm{~W} \mathrm{~m}^{-2}$ (shaded area in Fig. 1a). This region of active convection is enclosed by a rectangular domain between $10^{\circ} \mathrm{S}$ and $20^{\circ} \mathrm{N}, 40^{\circ} \mathrm{W}$ and $40^{\circ} \mathrm{E}$, shown by the heavy box in Fig. 1a. This is the domain on which the EOF analysis is performed in section 4. The southerly cross-equatorial flow over the western Indian Ocean that supplies the moisture to the Asian monsoon is outside this domain.

The mean flow over the region is dominated by various zonal jets (Fig. 1b). The westerly subtropical jets peak at the $200-\mathrm{hPa}$ level in both hemispheres, the Southern Hemisphere jet being the stronger at this time of year. In the Tropics, the mean flow has a westerly (a) OLR, v925 $\longrightarrow$

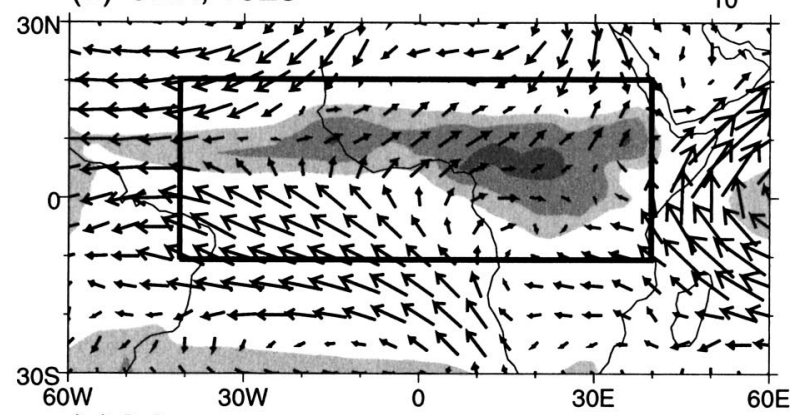

(b) [u]

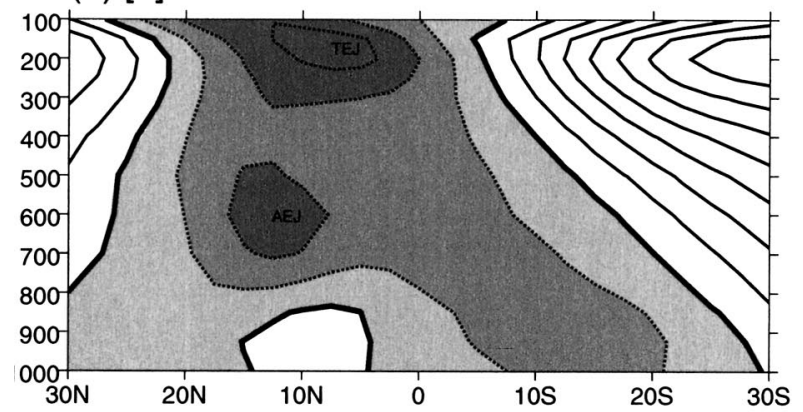
(c) $\mathrm{v} 700$ ( $<20$ days)

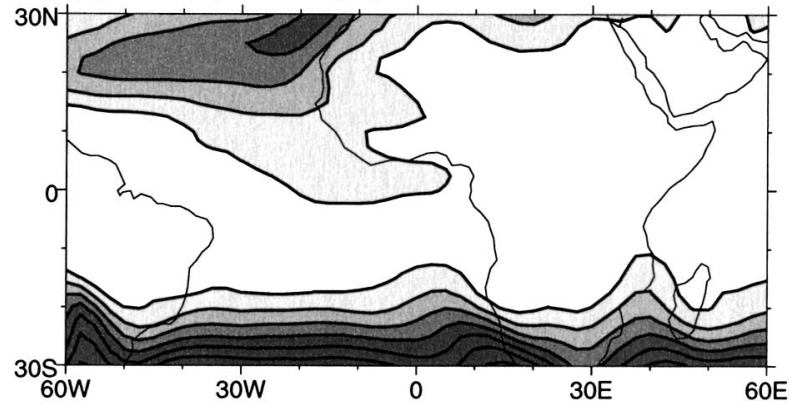

FIG. 1. Climatological mean fields for JAS 1975-2000: (a) OLR, values below $210 \mathrm{~W} \mathrm{~m}^{-2}$ are shaded with an interval of $20 \mathrm{~W} \mathrm{~m}^{-2}$; $925-\mathrm{hPa}$ wind vectors, reference vector is $10 \mathrm{~m} \mathrm{~s}^{-1}$. The box shows the domain over which the EOF analysis was performed. (b) Latitudepressure cross section of zonal wind $u$ averaged from $40^{\circ} \mathrm{W}$ to $40^{\circ} \mathrm{E}$. Contour interval is $4 \mathrm{~m} \mathrm{~s}^{-1}$ and negative values are shaded. (c) Standard deviation of 20-day high-pass filtered meridional wind $v$ at 700 $\mathrm{hPa}$. Contour interval is $0.5 \mathrm{~m} \mathrm{~s}^{-1}$ and first contour is at $2.5 \mathrm{~m} \mathrm{~s}^{-1}$.

component near the surface between $5^{\circ} \mathrm{N}$ and $15^{\circ} \mathrm{N}$, corresponding to the southwesterly monsoon flow described above in Fig. 1a. Above the 850-hPa level, the mean flow is easterly and shows two peaks, in the African easterly jet at $600 \mathrm{hPa}$ and the tropical easterly jet at $200 \mathrm{hPa}$, denoted by AEJ and TEJ in Fig. 1b, respectively.

The African easterly jet is barotropically and baroclinically unstable, and easterly waves grow on the jet (e.g., Thorncroft and Hoskins 1994a,b). These have a strong meridional wind $v$ component and tend to have maximum amplitude at approximately the 700-hPa level (Reed et al. 1977). The average period of the easterly waves is approximately 5 days; hence a useful diag- 
nostic for the amplitude of the easterly waves is the standard deviation of the high-frequency 700-hPa $v$ wind (Fig. 1c). The high-frequency winds are obtained by passing the total wind time series at each grid point through a 241-weight high-pass Lanczos filter with a cutoff frequency corresponding to a period of 20 days. The maximum amplitude is found in the subtropics and extratropics of both hemispheres, corresponding to the baroclinic waves in the storm tracks, but there is a secondary maximum along $15^{\circ} \mathrm{N}$ over west Africa and the Atlantic, corresponding to the easterly waves.

\section{Intraseasonal variability over Africa}

To determine the modes of intraseasonal variability of deep convection over tropical Africa, an EOF analysis of intraseasonal OLR anomalies was performed over the domain shown by the box in Fig. 1a. The 20-200-day bandpass filter is much wider than the 30-70-day variability associated with the $\mathrm{MJO}$, and the main regions of MJO convection are over the warm pool sector, which is outside the domain used here. Here, the EOF analysis should truly pick out the dominant modes of African intraseasonal variability, and not be a priori biased toward MJO variability.

The leading eigenvector from the EOF analysis accounted for $15.8 \%$ of the variance and was well separated from the second eigenvector, which accounted for $8.4 \%$ of the variance. In turn, the second eigenvector was well separated from the third, which together with the remaining eigenvectors were degenerate and could not be separated from sampling noise according to the criteria of North et al. (1982). The spatial structures (EOFs) were then dimensionalized by multiplying by the square root of their respective eigenvalue. Given the broadness of the 20-200-day filter, these leading EOFs account for a large fraction of the variance. For comparison, the MJO is accepted as the dominant mode of intraseasonal variability in the Tropics, yet an EOF analysis of 20-200-day filtered OLR over the whole tropical band had the first two EOFs (which described the MJO) as only accounting for $6.6 \%$ and $5.4 \%$ of the variance, respectively (Matthews 2000). When the analysis was carried out on a narrower 30-70-day bandpass filtered dataset, the leading EOFs accounted for much more variance.

The dominant mode of intraseasonal convective variability over Africa is an enhancement of the mean convection, as the negative OLR anomalies in EOF 1 (Fig. 2a) have a similar pattern to the region of low mean OLR (Fig. 1a), with maximum convective anomalies in a zonal band along $10^{\circ}-15^{\circ} \mathrm{N}$ and a southeastward-oriented band over central Africa. The principal component (PC) time series gives the amplitude of this spatial pattern on any given day and is shown for just one season, JAS 2000, in Fig. 2c. During the latter half of July 2000, the mode was in its positive phase with enhanced convection over tropical Africa. One month later, in late

\section{(a) EOF 1}

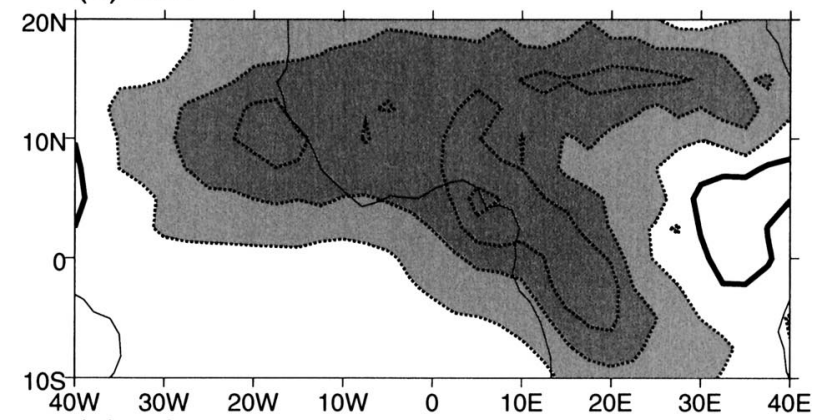

(b) EOF 2

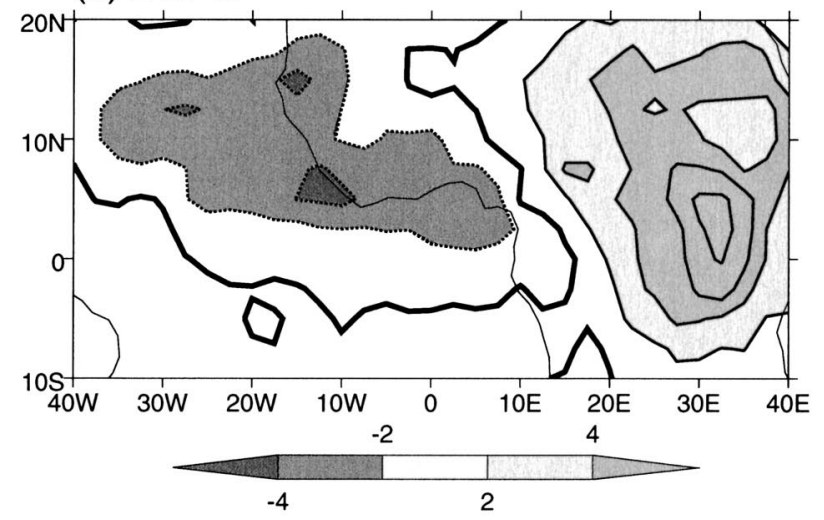

(c) PC time series

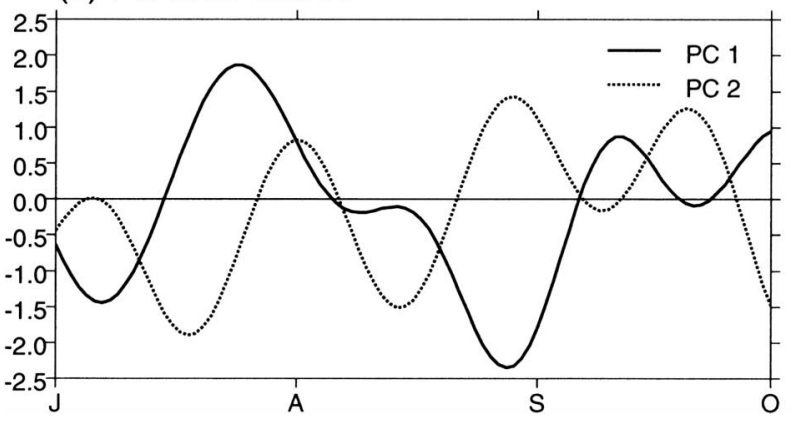

FIG. 2. EOF analysis of 20-200-day filtered OLR over tropical Africa $\left(10^{\circ} \mathrm{S}-20^{\circ} \mathrm{N}, 40^{\circ} \mathrm{W}-40^{\circ} \mathrm{E}\right)$ for JAS $1975-2000$ : (a) EOF 1 and (b) EOF 2. Contour interval is $2 \mathrm{~W} \mathrm{~m}^{-2}$; negative contours are dotted and the zero contour is bold. Shading is shown by the legend. (c) PC time series for JAS 2000. The tick marks on the horizontal axis show the first day of the month. PC 1 (PC 2) is shown by the solid (dashed) line.

August 2000, the mode was in its negative phase with reduced convection. This period coincided with the JET2000 field experiment (Thorncroft et al. 2003) from 25 to 30 August 2000, during which the detailed structure of African easterly waves was observed. Unfortunately, easterly wave activity and rainfall were strongly suppressed during JET2000, which may be due to the suppressed phase of the intraseasonal mode during that period. This will be discussed further in section 5 .

The second eigenvector describes a dipole pattern of convective activity (Fig. 2b). In its positive phase there is enhanced convection (negative OLR anomalies) over 
(a) Day -20

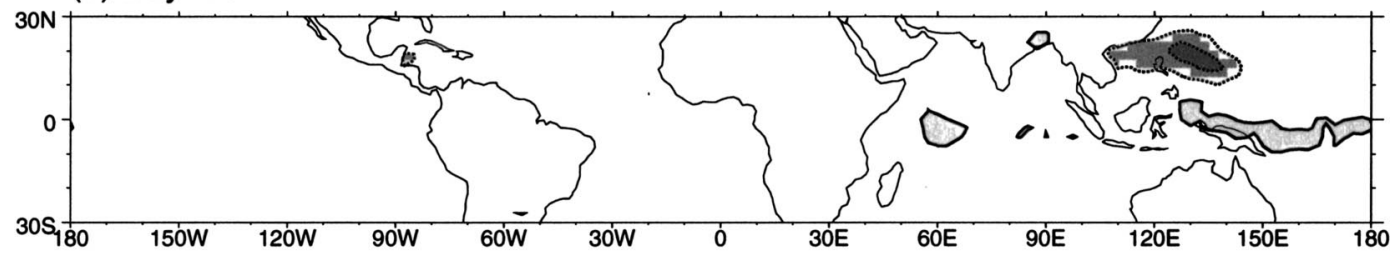

(b) Day -10

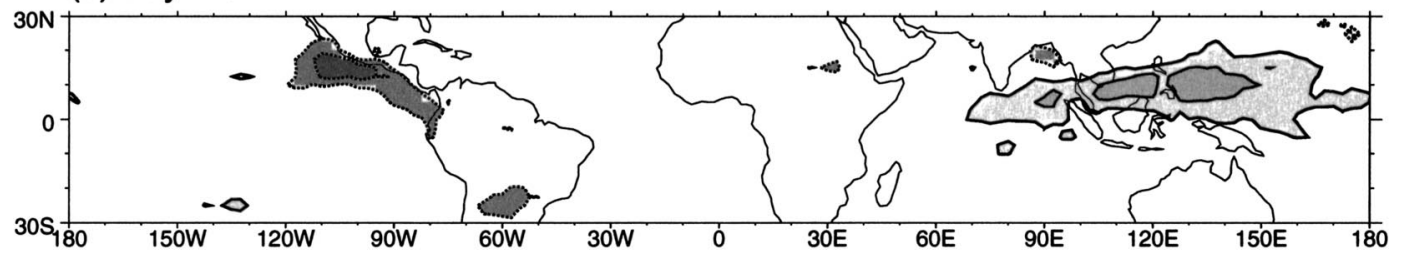

(c) Day 0

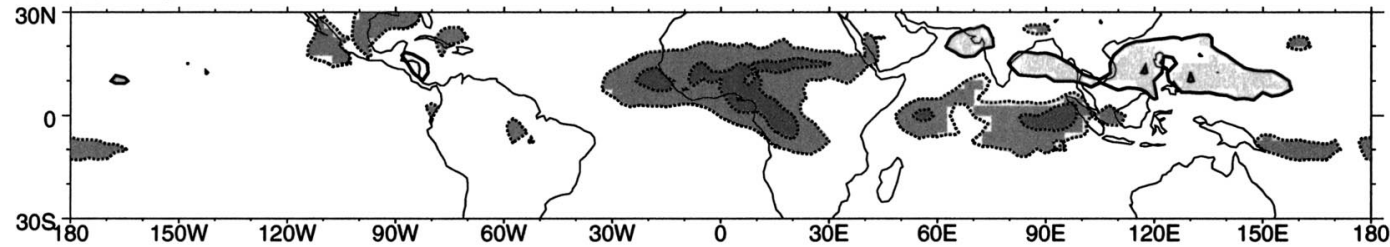

(d) Day 10

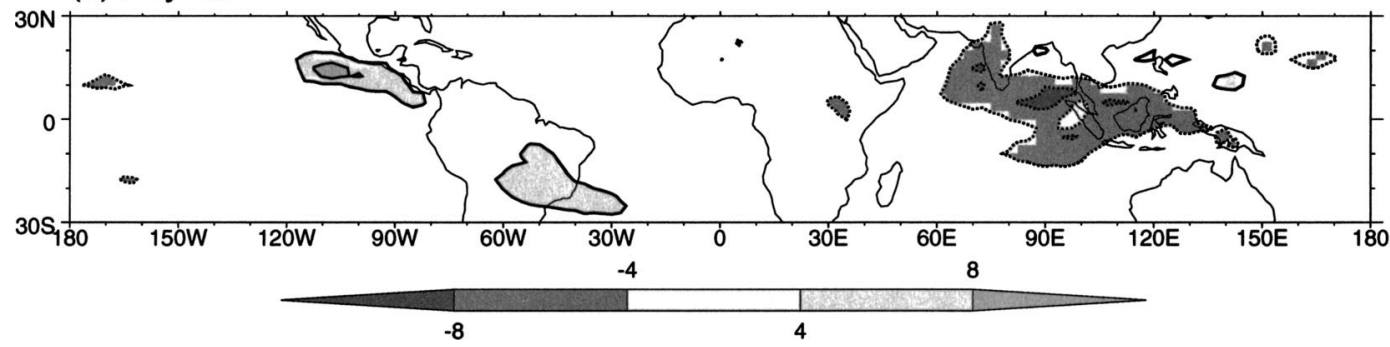

FIG. 3. Lagged regression maps of OLR anomalies on (a) day -20 , (b) day -10 , (c) day 0, (d) and day 10. Contour interval is $4 \mathrm{~W} \mathrm{~m}^{-2}$; negative contours are dashed and the zero contour is omitted. Shading is shown by the legend and only anomalies locally significant at the $95 \%$ level are shaded.

West Africa and the Atlantic, and reduced convection over East Africa. The PC 2 time series for JAS 2000 (dotted line in Fig. 2c) shows no obvious relationship with PC 1 . When all 25 summers were analyzed, PC 1 and PC 2 were significantly lag-correlated at the $95 \%$ level. The critical correlation coefficient at the $95 \%$ level $r_{95}$ was calculated according to Livezey and Chen (1983). There were 2300 data samples and the decorrelation time scale was 10.4 days; hence there were 221 degrees of freedom and $r_{95}=0.113$. The peak correlation coefficient is $r=-0.288$ at a lag of 10 days. This implies that PC 2 is a minimum, with enhanced convection over East Africa and reduced convection over West Africa, 10 days before PC 1 peaks, with enhanced convection over most of the domain, peaking over central Africa. This scenario is one of westward propagation of an enhanced convective anomaly over Africa. However, as only $8 \%$ of the variance $\left(r^{2}\right)$ in PC 2 can be accounted for by PC 1 , this relationship is extremely weak and EOF 2 will not be discussed further.

\section{Global structure}

\section{a. Global convective anomalies}

The development of deep convective anomalies over the entire tropical belt during the "life cycle" of an African intraseasonal oscillation can be described by a sequence of lagged regression maps of OLR, lagged with respect to PC 1. Local statistical significance at each grid point was determined by comparing the value of the correlation coefficient $r$ between the OLR time series at that grid point with the PC 1 time series. If $|r|>r_{95}$, the regression map was deemed significant at that grid point.

On day 0 (Fig. 3c), which corresponds to the time when PC 1 is a maximum, the OLR anomalies over Africa had a very similar pattern to those in EOF 1, with enhanced convection over the whole region of active convection. However, there were also large amplitude convective anomalies elsewhere in the Tropics, particularly over the warm pool region, with a zonal band 
(a) 7 July 1998: Day -10

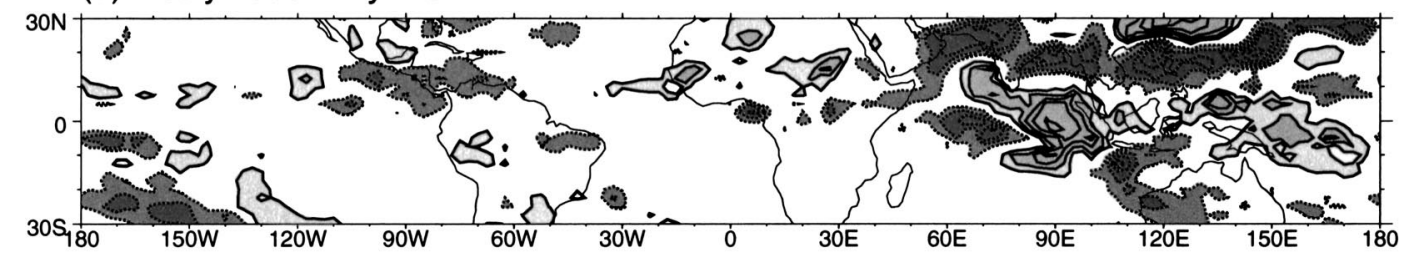

(b) 17 July 1998: Day 0

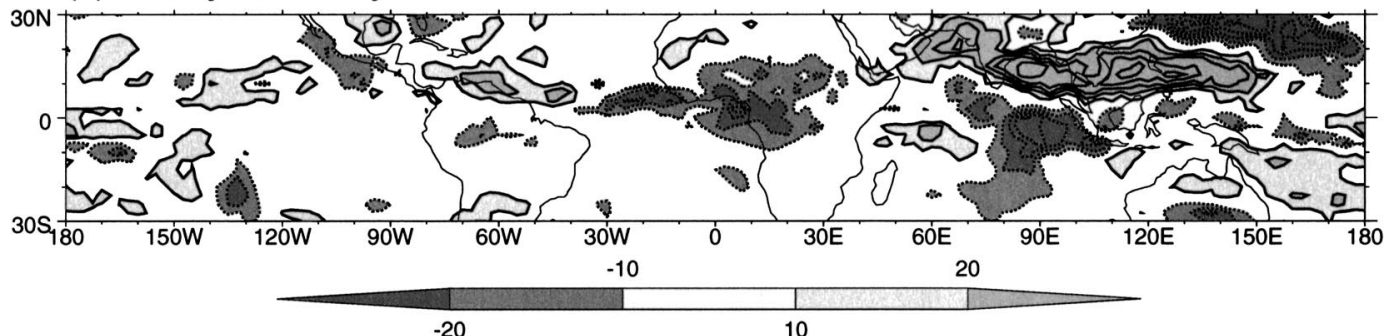

FIG. 4. Anomalous 20-200-day filtered OLR on (a) 7 and (b) 17 Jul 1998. Contour interval is $10 \mathrm{~W} \mathrm{~m}^{-2}$; negative contours are dashed and the zero contour is omitted.

of enhanced convection along the equator over the Indian Ocean and the western Pacific and a zonal band of reduced convection along $10^{\circ}-15^{\circ} \mathrm{N}$.

Twenty days prior to the peak in convection over Africa, there were no convective anomalies over Africa but there was a reversal of the convective signal over the warm pool sector, with reduced convection along the equator and enhanced convection to the north (Fig. 3a). Ten days later (Fig. 3b), the band of reduced convection had moved northward to $10^{\circ} \mathrm{N}$ and the enhanced convection had disappeared. There was also a region of enhanced convection over the extreme eastern Pacific, off the coast of Central America. This was associated with SST anomalies of up to $0.2^{\circ} \mathrm{C}$ (not shown) and appeared to be the eastern Pacific response to the MJO identified by Maloney and Kiehl (2002). By day 0 (Fig. $3 c)$, the enhanced convection over Africa had developed. Over the warm pool sector the band of reduced convection had moved farther northward to $10^{\circ}-15^{\circ} \mathrm{N}$, and the band of enhanced convection had appeared along the equator. By day 10 (Fig. 3d), the anomalous African convection had disappeared, and the enhanced convection over the warm pool had moved northward off the equator. This northward propagation of bands of convective anomalies over the warm pool sector can be identified as the tropical intraseasonal oscillation or MJO during northern summer (e.g., Knutson et al. 1986; Annamalai and Slingo 2001).

Only anomalies significant at the $95 \%$ level were shown in the regression maps of Fig. 3. A qualitative further test of the significance of this mode of variability can be gained from a snapshot of the OLR anomaly field on a day when PC 1 peaks. For example, 17 July 1998 was such a day (Fig. 4b), and the anomalies clearly correspond to the day 0 regression pattern in Fig. 3c, with enhanced convection over tropical Africa and the equatorial Indian Ocean with a band of reduced con- vection over the warm pool sector along $10^{\circ} \mathrm{N}$. Elsewhere, the negative anomaly along $20^{\circ}-30^{\circ} \mathrm{N}$ that was present over the western Pacific on 17 July 1998 does not seem to be part of the average life cycle in Fig. 3c. Ten days previously, on 7 July 1998 (Fig. 4a), the OLR anomalies correspond to the day -10 regression pattern (Fig. 3b) with no significant convective anomalies over Africa and reduced convection over the equatorial warm pool and a band of enhanced convection to the north.

\section{b. Equatorial Kelvin wave}

The appearance of the warm pool sector convective anomalies 20 days before the enhanced convection over Africa in Fig. 3 suggests that the African convection may arise as a forced response to the warm pool convection and associated latent heat release, possibly via an equatorial wave mechanism. The anomalies shown here can be superimposed onto a mean state, which includes mean convection and latent heat release over the western Pacific, that is in equilibrium with the mean pressure and wind fields. Part of this equilibrium will involve an equatorial Kelvin wave response to the east of the mean convection.

On day -20 there was a weak negative convective anomaly over the western Pacific (Fig. 3a). This would be associated with a negative latent heating anomaly (a cooling anomaly) or equivalently a reduction in the total heating. The dynamical response to such an anomaly would be an anomalous equatorial Kelvin wave response to the east, of opposite sign to that of the mean flow. The near-surface $925-\mathrm{hPa}$ geopotential height and wind anomalies did show such a weak Kelvin wave signal on day -20 (Fig. 5a). A positive geopotential height or high pressure anomaly was collocated with the reduced convection over the equatorial western $\mathrm{Pa}$ cific and extended eastward along the equator into the 
(a) Day -20

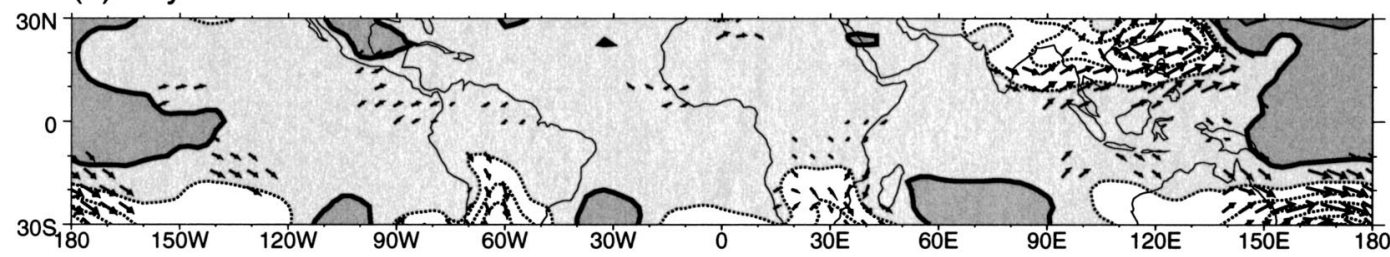

(b) Day -10

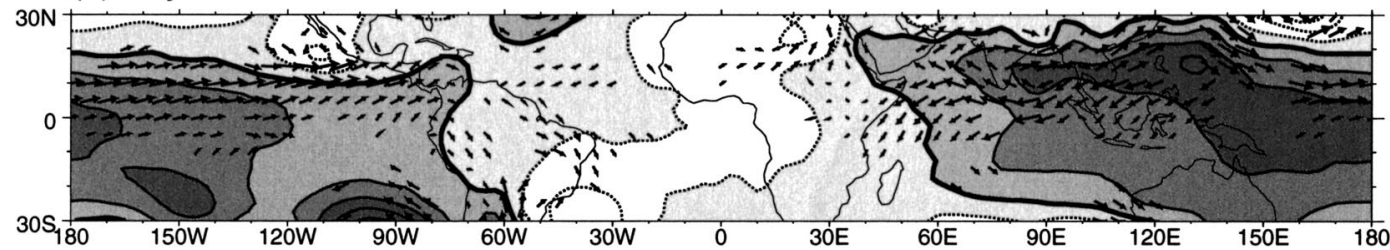

(c) Day 0

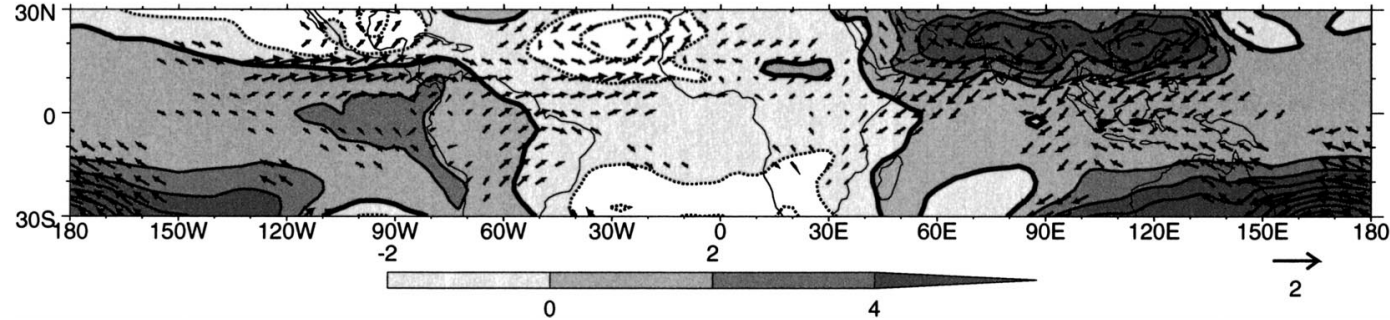

FIG. 5. Lagged regression maps of $925-\mathrm{hPa}$ geopotential height and vector wind anomalies on (a) day -20, (b) day -10 , and (c) day 0 . Contour interval for geopotential height is $2 \mathrm{~m}$; values above $-2 \mathrm{~m}$ are shaded; the zero contour is bold and negative contours are dotted. Reference wind vector is $2 \mathrm{~m} \mathrm{~s}^{-1}$. Only wind vectors locally significant at the $95 \%$ level are plotted.

central Pacific as a Kelvin wave (cf. Bantzer and Wallace 1996; Milliff and Madden 1996; Matthews 2000). Consistent with the Kelvin wave pressure signal, there were westerly anomalies over the central Pacific, though these were a maximum along $10^{\circ} \mathrm{N}$ rather than at the equator.

By day -10 the negative convective anomaly over the warm pool had strengthened (Fig. 3b), and its Kelvin wave response had strengthened and propagated farther eastward with larger positive $925-\mathrm{hPa}$ geopotential height and zonal wind anomalies over the entire equatorial Pacific (Fig. 5b). The Kelvin wave appeared to have been blocked by the Andes mountain range, as in Matthews (2000). Part of the surface pressure signal propagated southward on the western side of the Andes and part of it propagated through the gap at Panama between the Andes and the Central American mountain ranges. This part then propagated across the Atlantic as an equatorial Kelvin wave, such that by day 0 there was an equatorial maximum in pressure over the Atlantic with accompanying westerly anomalies (Fig. 5c).

Positive SST anomalies appeared over the equatorial Atlantic between day -5 and day 5 (not shown). These are consistent with the anomalous surface westerlies, which would reduce the strength of the mean easterly trade winds and the latent heat flux from the ocean. However, the anomalies were very weak (up to $0.05^{\circ} \mathrm{C}$ ) and not statistically significant and do not appear to be an important component of the variability described here.

The Kelvin wave propagation can be seen more clearly in the independent midtropospheric MSU34 (combination of MSU channels 3 and 4) temperature anomalies. On day -10 , there was a large negative temperature anomaly within the region of reduced convection over the warm pool (Fig. 6a). An equatorial tongue of negative temperature anomalies extended to the east as a Kelvin wave over the Pacific and Atlantic, with slight southward propagation along the Andes also evident. An equatorial Rossby wave structure could also be seen with off-equatorial minima extending westward from the negative convective anomaly over the Indian Ocean into East Africa. This equatorial Rossby wave response could also be seen as two off-equatorial high pressure and anticyclonic wind anomalies in the lower troposphere (Fig. 5b). By day 0 the eastward-propagating Kelvin wave and the slower westward-propagating Rossby wave had between them completed a circuit of the equator such that they met over Africa (Fig. 6b), and there were negative temperature anomalies around the entire equatorial belt. Correlation maps of MSU34 temperature anomalies at day -10 and day 0 (not shown) indicate that $25 \%-35 \%$ of the variance of the intraseasonal midtropospheric temperature anomalies associated with African convection can be ascribed to the equatorial waves. 
(a) Day -10

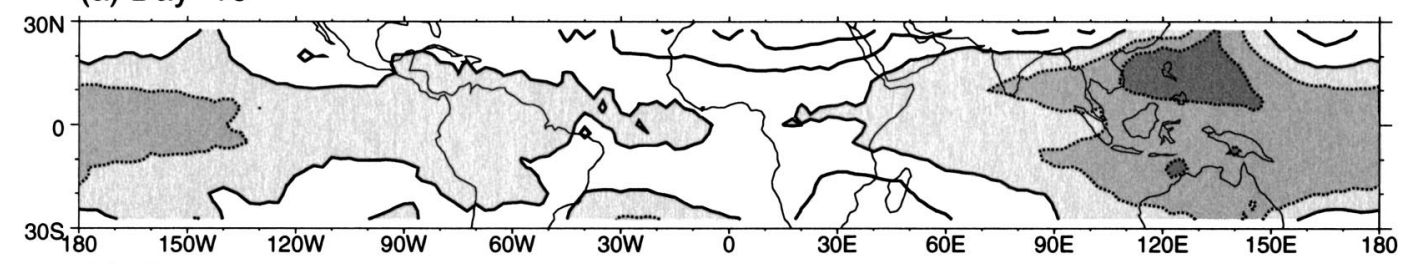

(b) Day 0

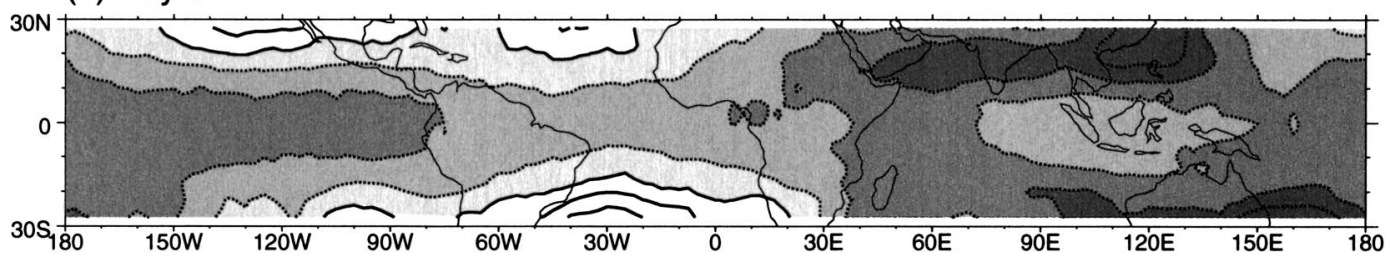

FIG. 6. Lagged regression maps of anomalous midtropospheric temperature MSU34 on (a) day -10 and (b) day 0. Contour interval is $0.08 \mathrm{~K}$; negative values are shaded.

This propagation can be clearly seen in a Hovmöller diagram of equatorial (averaged from $10^{\circ} \mathrm{S}$ to $10^{\circ} \mathrm{N}$ ) temperature anomalies (Fig. 7). The peak signal emanated from approximately $140^{\circ} \mathrm{E}$ over the warm pool on day -5 and propagated eastward (as a Kelvin wave) at an average speed of $33 \mathrm{~m} \mathrm{~s}^{-1}$ and westward (as a Rossby wave) at an average speed of $19 \mathrm{~m} \mathrm{~s}^{-1}$, meeting at $5^{\circ} \mathrm{E}$ on day 4. The ratio of Kelvin to Rossby wave speeds is only 1.7 , rather than 3 as predicted by linear wave theory (Gill 1980). However, there are other factors that are not present in the simple linear model, such as the effect of the background mean winds and interaction with convection and orography.

The vertical structure of the equatorial waves along

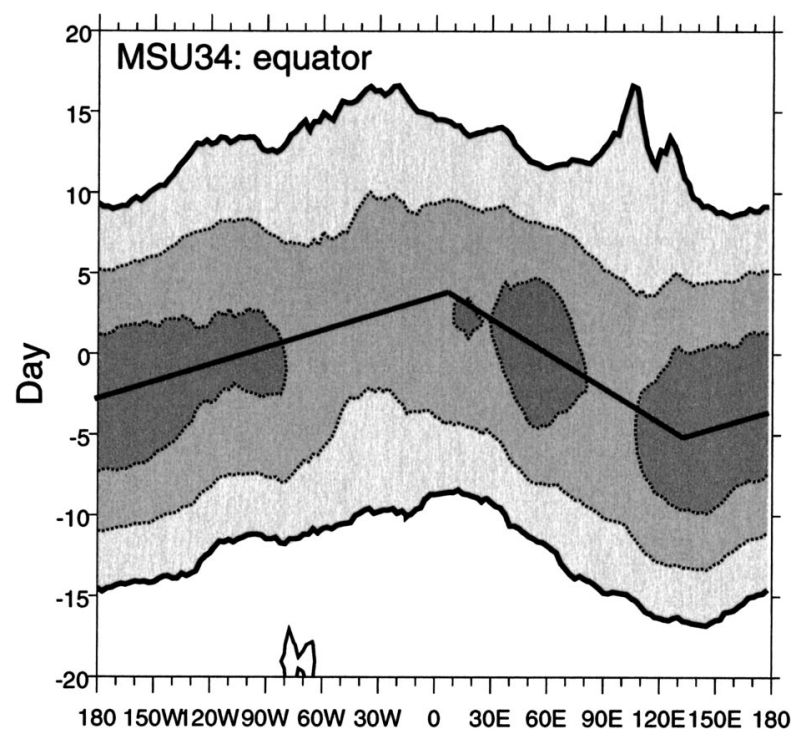

FIG. 7. Hovmöller diagram of regressed anomalous equatorial midtropospheric temperature MSU34 averaged from $10^{\circ} \mathrm{S}$ to $10^{\circ} \mathrm{N}$. Contour interval is $0.08 \mathrm{~K}$; negative values are shaded and negative contours are dotted. The thick straight lines indicate the average propagation speed of the peak anomalies. the equator was primarily a first internal mode, consistent with forcing by a midtropospheric heat source from anomalous deep convection. On day -10 , the negative heating anomaly over the warm pool between $80^{\circ} \mathrm{E}$ and the date line led to anomalous descent and adiabatic warming (Fig. 8), which would partially offset the anomalous diabatic cooling there. The equatorial Kelvin wave response to the east consisted of lower-tropospheric westerly and high pressure anomalies and uppertropospheric easterly and low pressure anomalies with the nodal point at approximately $450 \mathrm{hPa}$. The anomalous diabatic cooling signal over the warm pool forcing region was spread eastward by the adiabatic cooling associated with the ascent in the Kelvin wave front, which extended from $120^{\circ}$ to $40^{\circ} \mathrm{W}$ at this time.

The equatorial Rossby wave signal can also be seen in this cross section, with lower-tropospheric easterly and high pressure anomalies extending from the western edge of the diabatic cooling at $90^{\circ} \mathrm{E}$ westward to the Rossby wave front at $40^{\circ} \mathrm{E}$ where there was weak ascent throughout the troposphere. The Rossby wave structure was not evident in the upper troposphere, where nonlinear effects may have masked it. It should also be noted that the Rossby wave signal would be a maximum off the equator at approximately $15^{\circ}$ latitude.

\section{c. Mechanisms for the enhancement of convection over Africa}

The anomalous equatorial Kelvin wave front that propagated eastward from the warm pool region and reached the Atlantic and West Africa by day 0 forced deep anomalous ascent over this region and lowered the temperature in the middle troposphere by adiabatic cooling. This would tend to destabilize the troposphere and favor anomalous deep convection as observed (Fig. 3c). This process would then contribute to the enhanced upper-tropospheric divergence over West Africa, and the subsequent divergent outflow, which mainly formed an 


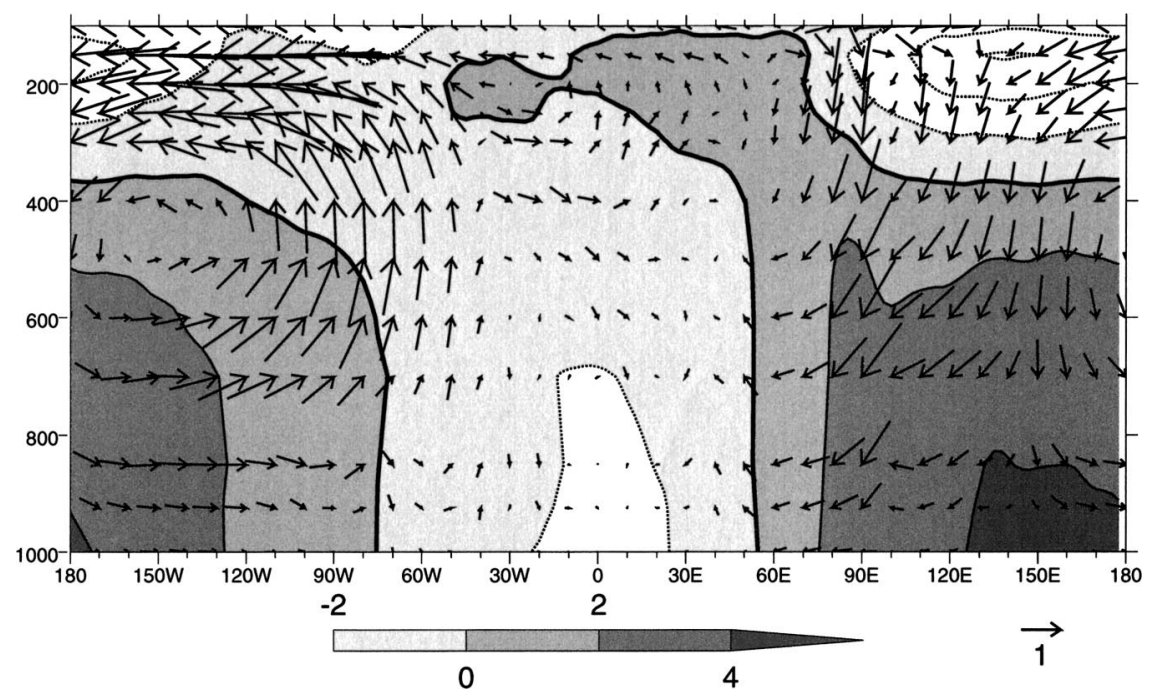

FIG. 8. Longitude-pressure cross section of regressed geopotential height $Z$, zonal wind $u$, and vertical pressure velocity $\omega$ anomalies along the equator (averaged from $10^{\circ} \mathrm{S}$ to $10^{\circ} \mathrm{N}$ ) on day -10 . Geopotential height contour interval is $2 \mathrm{~m}$; values above $-2 \mathrm{~m}$ are shaded; the zero contour is bold and negative contours are dotted. Zonal and vertical wind is plotted as a pseudovector, the reference vector corresponds to $1 \mathrm{~m} \mathrm{~s}^{-1}$ for $u$ and $3 \mathrm{hPa}$ day ${ }^{-1}$ for $\omega$.

anomalous local Hadley-type circulation into the Southern Hemisphere (Fig. 9a).

Similarly, the equatorial Rossby wave that had propagated westward from the warm pool region and reached eastern and central Africa by day 0 also forced deep anomalous ascent, cooled the midtroposphere, destabilized the atmospheric column, and induced deep convection. The strongest regions of ascent and negative midtropospheric temperature anomalies in the equatorial Rossby wave were centered off the equator, corresponding to the off-equatorial anomalous convective maxima at $10^{\circ} \mathrm{N}$ and $10^{\circ} \mathrm{S}$ over eastern and central Africa (Fig. $3 c)$.

The Kelvin wave also had boundary layer westerly anomalies over the Atlantic and West Africa (Fig. 5c). These anomalous winds were of the order of $1 \mathrm{~m} \mathrm{~s}^{-1}$, compared to a climatological mean wind speed of between zero and $5 \mathrm{~m} \mathrm{~s}^{-1}$ over the region (Fig. 1a). These anomalous winds would enhance the advection of moisture by a similar amount into West Africa by the mean monsoon circulation (Fig. 1a), leading to positive humidity anomalies in the region (Fig. 9b) that would fuel the enhanced convection. Once the convection over Africa was established, it could then force its own dynamical response. The anomalous low-level subtropical cyclone centered at $20^{\circ} \mathrm{N}, 30^{\circ} \mathrm{W}$ may be attributable to an equatorial Rossby wave response to the enhanced African convection. The anomalous westerly and southwesterly flow on the equatorward flank of this cyclone would then also act to increase the monsoonal moisture flux, providing a positive feedback between the convection and the circulation. It is difficult to separate cause and effect within an observational analysis; this will be addressed by future modeling studies.
In addition to destabilizing the atmosphere and enhancing the mean moisture supply to West Africa, the arrival of the Kelvin wave changed the basic-state circulation upon which the rain-bearing easterly waves grow. The easterly waves grow through a combination of barotropic and baroclinic instability of the African easterly jet, which peaks at the $600-700-\mathrm{hPa}$ level. On day 0 , there was a westerly 700 -hPa equatorial anomaly over the Atlantic and West Africa due to the Kelvin wave and an easterly anomaly at $20^{\circ} \mathrm{N}$ (Fig. 9c). The cyclonic shear of these wind anomalies (Fig. 9d) increased the total cyclonic shear on the equatorward flank of the African easterly jet. The African easterly jet would then be more barotropically unstable and would lead to an increase in easterly wave activity, as shown by the positive anomaly in the variance of the highfrequency (20-day high-pass filtered) $700-\mathrm{hPa}$ meridional wind over West Africa (Fig. 9e). Consistent with this increase in easterly wave activity, there was also an increase in high-frequency convective activity (variance of 20-day high-pass filtered OLR, Fig. 9f) over West Africa. This increase in transient convective activity around day 0 and the concomitant decrease in transient convective activity in the opposite phase of the cycle would then rectify onto the longer intraseasonal time scale and contribute to the increase in the slowly varying envelope of convection observed over West Africa on day 0 . It is possible that the unusually low level of transient wave and convective activity observed during the JET2000 field experiment (Thorncroft et al. 2003) in late August 2000 was due to these processes, as the intraseasonal mode was in its negative phase during that period (Fig. 2c). 
(a) 200-hPa D, vchi

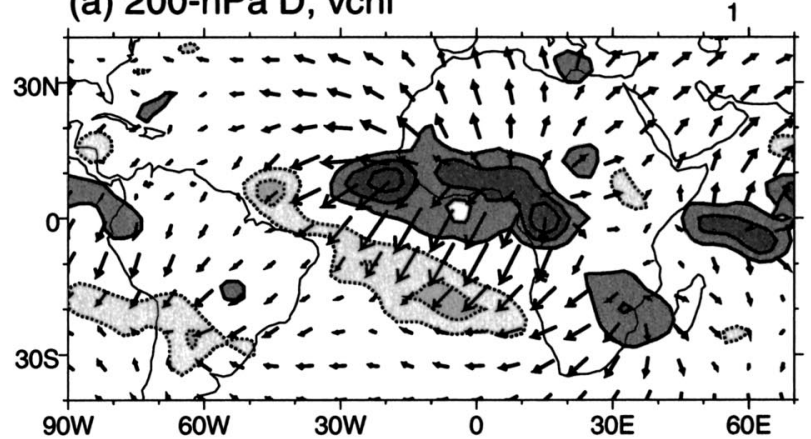

(b) $925-\mathrm{hPa} q$

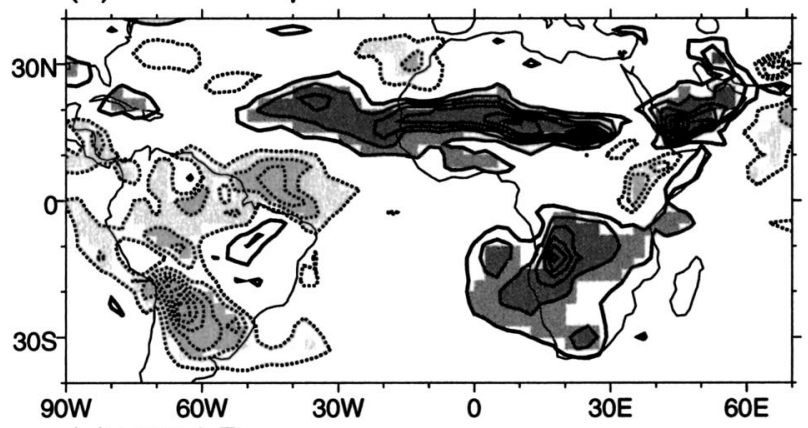

(c) 700-hPa u

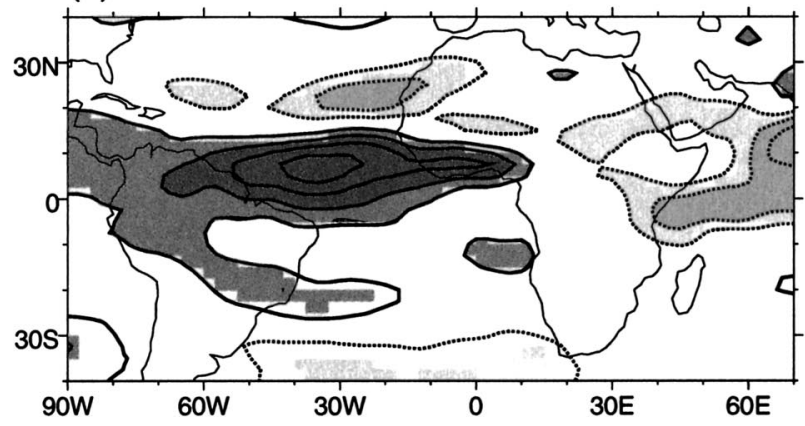

(d) 700-hPa vorticity

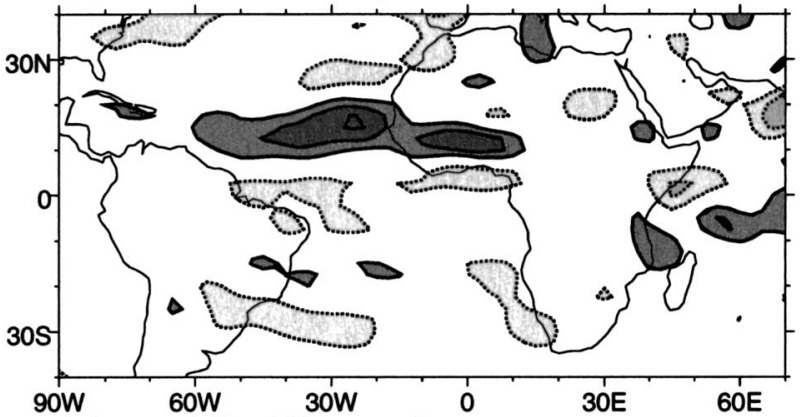

(e) $700-\mathrm{hPa} H F \mathrm{v}$ variance

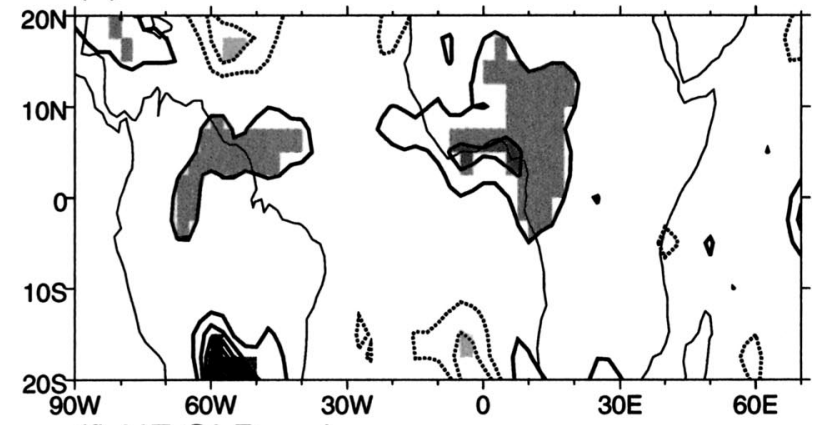

(f) HF OLR variance

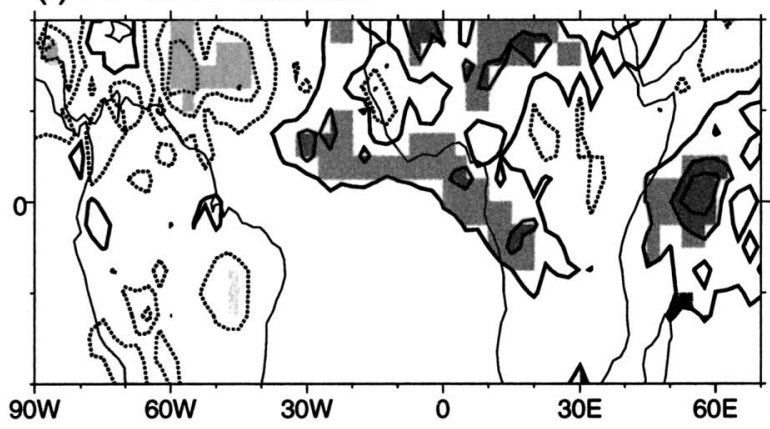

FIG. 9. Regression maps on day 0. (a) Anomalous 200-hPa divergence $D$ and divergent wind $\mathbf{v}_{\gamma}$. Contour interval for $D$ is $4 \times 10^{-7} \mathrm{~s}^{-1}$; the zero contour is omitted. The reference wind vector is $1 \mathrm{~m} \mathrm{~s}^{-1}$. (b) Anomalous 925 -hPa specific humidity $q$. Contour interval is $0.1 \mathrm{~g}$ $\mathrm{kg}^{-1}$; the zero contour is omitted. Anomalies above $0.1 \mathrm{~g} \mathrm{~kg}^{-1}$ are shaded darkly and below $-0.1 \mathrm{~g} \mathrm{~kg}^{-1}$ are shaded lightly. Only anomalies locally significant at the $95 \%$ level are shaded. (c) Anomalous $700-\mathrm{hPa}$ zonal wind $u$. Contour interval is $0.4 \mathrm{~m} \mathrm{~s}^{-1}$; the zero contour is omitted. Anomalies above $0.4 \mathrm{~m} \mathrm{~s}^{-1}$ are shaded darkly and below $-0.4 \mathrm{~m} \mathrm{~s}^{-1}$ are shaded lightly. Only anomalies locally significant at the 95\% level are shaded. (d) Anomalous 700-hPa relative vorticity. Contour interval is $1 \times 10^{-6} \mathrm{~s}^{-1}$; the zero contour is omitted. (e) Anomalous 20-day high-pass 700-hPa meridional wind variance. Contour interval is $0.4 \mathrm{~m}^{2} \mathrm{~s}^{-2}$; the zero contour is omitted. Anomalies above 0.4 $\mathrm{m}^{2} \mathrm{~s}^{-2}$ are shaded darkly and below $-0.4 \mathrm{~m}^{2} \mathrm{~s}^{-2}$ are shaded lightly. Only anomalies locally significant at the $95 \%$ level are shaded. (f) Anomalous 20-day high-pass OLR variance. Contour interval is $60 \mathrm{~W}^{2} \mathrm{~m}^{-4}$, and the first positive contour is at $30 \mathrm{~W}^{2} \mathrm{~m}^{-4}$. Anomalies above $30 \mathrm{~W}^{2} \mathrm{~m}^{-4}$ are shaded darkly and below $-30 \mathrm{~W}^{2} \mathrm{~m}^{-4}$ are shaded lightly. Only anomalies locally significant at the $95 \%$ level are shaded.

\section{Conclusions}

The structure of the dominant mode of intraseasonal variability of the African northern summer monsoon has been determined, based on 25 years of NCEP-NCAR reanalysis and satellite data. The mode had the form of enhanced convection over West Africa and enhanced off-equatorial convection in both hemispheres over eastern and central Africa. It appeared to arise at least partly as a remote response to convective anomalies over the warm pool associated with the MJO. Twenty days before the appearance of convective anomalies over Africa, there was a band of reduced convection over the equatorial warm pool. This forced a "negative" anomalous equatorial Kelvin and Rossby wave response that propagated eastward and westward, respectively. Eventually the two waves completed a circuit of the globe and met up 20 days later over Africa. The wave fronts had anomalous deep ascent and negative midtropospheric temperature anomalies associated with them and acted to destabilize the troposphere and trigger anomalous deep convection over Africa (Fig. 10). The maximum ascent, midtropospheric cooling, and convection due to the 


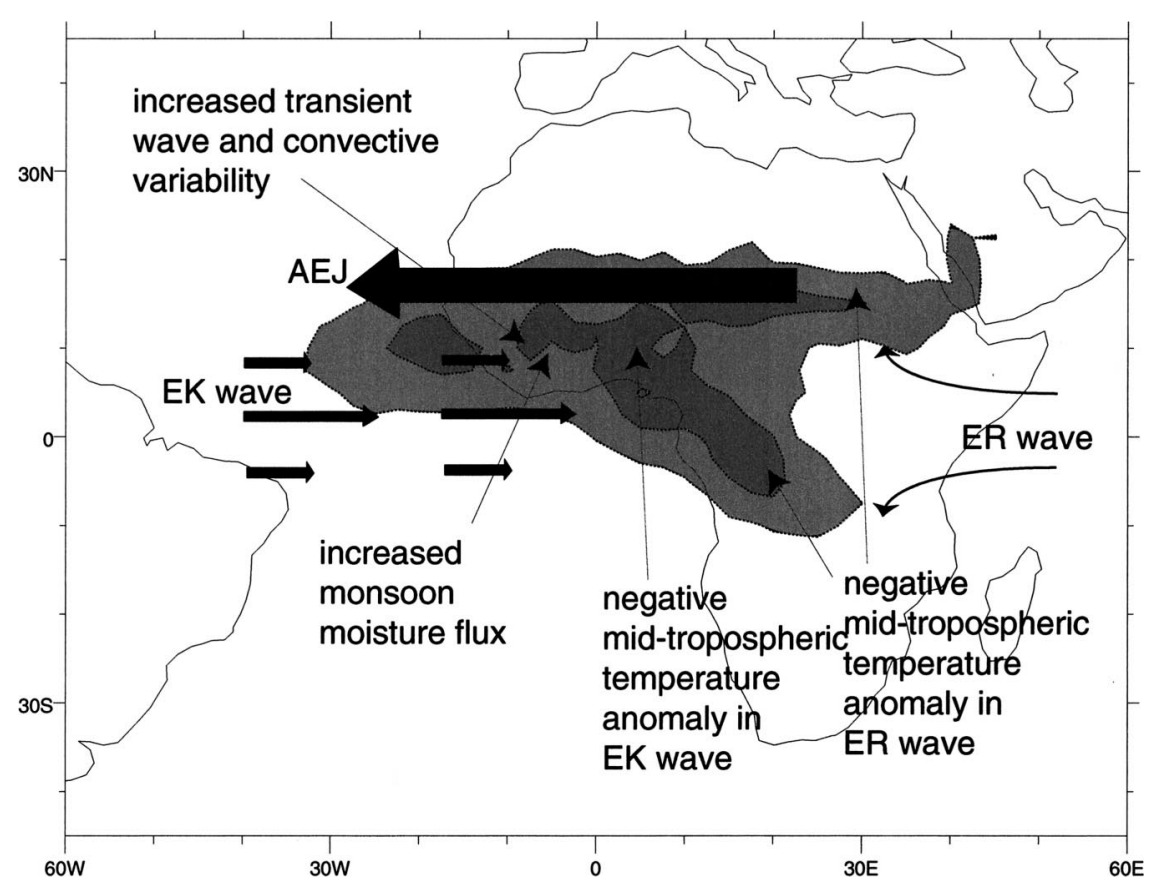

FIG. 10. Schematic diagram of the dynamical and physical processes leading to enhanced intraseasonal convection over Africa. The equatorial Kelvin and Rossby waves are denoted by EK and ER, respectively, and the African easterly jet by AEJ.

equatorial Rossby wave was located off the equator in two bands, at $10^{\circ} \mathrm{N}$ and $10^{\circ} \mathrm{S}$, over central and eastern Africa. The maximum ascent, midtropospheric cooling and convection due to the equatorial Kelvin wave was concentrated along a single line of latitude over West Africa. In addition to this direct forcing of convection over Africa, the equatorial Kelvin wave also acted to (i) increase the surface monsoon flow and moisture supply into West Africa by up to $20 \%$ and (ii) increase the cyclonic shear on the equatorward flank of the African easterly jet, which enhanced the barotropic instability of the jet and led to enhanced African easterly wave and transient convective activity (Fig. 10). Both of these processes then contributed to the enhanced convection over Africa on the intraseasonal time scale. Quantitative calculations of the effect of increasing the shear of the African easterly jet are being carried out in a further model study.

The "direct" equatorial wave forcing of African convection may also operate on the interannual time scale. During El Niño events, the enhanced convection over the central Pacific forces an equatorial Kelvin wave that propagates eastward over South America and the Atlantic to Africa. Anomalous SST gradients between the Indian Ocean and the western Pacific also force deep convection and an equatorial Rossby wave that propagates westward to Africa. The subsidence in the wave fronts of both of these waves then leads to suppressed convection and reduced rainfall over the Sahel (Rowell 2001). However, on these longer time scales, an equilibrium equatorial wave response would be set up, with surface friction and other damping processes being crucial in determining the exact position of the subsidence region. The propagation speed and timing of the wave arrivals would not be so directly important.

The MJO is known to interact with high-frequency transient circulations and convection during northern winter over the eastern Pacific (Matthews and Kiladis 1999) and the Indian Ocean-western Pacific sector (Hall et al. 2001). It would be of interest to see whether the interactions over Africa during summer that are described in this paper also occur during winter. Another aspect of this scale interaction that is not currently known is the relationship between the 30-70-day MJOrelated variability over Africa discussed in this paper and the 15-day variability described by Janicot and Sul$\tan (2001)$.

Hurricanes in the Atlantic basin often develop from African easterly waves that have propagated westward across the Atlantic, and there is a strong association between West African monsoon rainfall and intense Atlantic hurricanes on the seasonal time scale (Landsea and Gray 1992). On interannual time scales, El Niño events are associated with suppressed Atlantic hurricane activity, as the vertical shear is increased over the Atlantic (Goldenberg and Shapiro 1996), and the changes in Atlantic hurricane activity are highly correlated with changes in African easterly wave activity (Thorncroft and Hodges 2001). During the positive phase (day 0) of the intraseasonal mode presented here, the vertical shear over the Atlantic was reduced and there was an enhancement in the African easterly wave activity, the 
hurricane "source." Both of these factors may have contributed to the enhanced Atlantic hurricane activity, which has been observed to occur during this phase of the MJO (Maloney and Hartmann 2000). Similarly, during northern winter the MJO strongly affects the numbers of tropical cyclones in the Indian Ocean and western Pacific basins (Hall et al. 2001), although this appeared to be due to changes in low-level vorticity.

Hence, it appears that the MJO, African convection, African easterly wave activity, and Atlantic hurricane activity are bound together in a series of complex scale interactions, and accurate prediction of variability in one component may need accurate prediction of the other components (Meehl et al. 2001). In particular, the enhancement of African convection and African easterly wave activity on intraseasonal time scales during northern summer was preceded by suppressed MJO convection over the equatorial warm pool 20 days previously. Such a relationship on its own may give useful predictability for Africa with a 20-day lead time, depending on the relative importance of the MJO compared to other factors such as stochastic forcing. If the subsequent development of the MJO could be accurately predicted this could increase the skill of a forecast further. The ability of atmospheric models to simulate and predict the mechanisms and patterns of intraseasonal variability over Africa is not known and is worthy of future study.

However, even the MJO itself is not well simulated in most atmospheric general circulation models (Slingo et al. 1996). In the case of the NCEP atmospheric forecast model, even when it was initialized with an active MJO, this MJO structure degraded in the resulting forecast and was essentially lost after approximately 7 days (Hendon et al. 2000; Jones et al. 2000). The reason for this is not clear, but is possibly due to the lack of airsea interaction processes. Hence, coupled ocean-atmosphere models may be necessary to improve the simulation of the MJO (Inness and Slingo 2003) but inclusion of these processes is certainly not a panacea (Hendon 2000). However, statistical prediction models of the MJO do currently show significant promise with skillful predictions made out to 15-20 days lead time (Waliser et al. 1999; Lo and Hendon 2000; Mo 2001; Wheeler and Weickmann 2001). Such models could be applied to forecast intraseasonal variability over Africa. Ultimately it is hoped that the dynamically and physically based models will succeed in accurately modeling the $\mathrm{MJO}$, and the simulation of the behavior and mechanisms presented in this paper would be a suitable test for them.

Acknowledgments. The NCEP/NCAR reanalysis, OLR, MSU, and SST data were obtained from the Climate Diagnostics Center (http://www.cdc.noaa.gov). I thank Doug Parker, Chris Thorncroft, Aida Diongue, Mariane Diop, and three anonymous reviewers for useful discussions and comments that helped to improve the manuscript.

\section{REFERENCES}

Annamalai, H., and J. M. Slingo, 2001: Active/break cycles: Diagnosis of the intraseasonal variability of the Asian summer monsoon. Climate Dyn., 18, 85-102.

,,-- K. R. Sperber, and K. Hodges, 1999: The mean evolution and variability of the Asian summer monsoon: Comparison of ECMWF and NCEP-NCAR reanalyses. Mon. Wea. Rev., 127, 1157-1186.

Bantzer, C. H., and J. M. Wallace, 1996: Intraseasonal variability in tropical mean temperature and precipitation and their relation to the tropical 40-50 day oscillation. J. Atmos. Sci., 53, 3032-3045.

Burpee, R. W., 1972: The origin and structure of easterly waves in the lower troposphere of North Africa. J. Atmos. Sci., 29, 7790 .

Camberlin, P., 1996: Intraseasonal variations of June-September rainfall and upper-air circulation over Kenya. Theor. Appl. Climatol., 54, 107-115.

Cook, K. H., 1999: Generation of the African easterly jet and its role in determining West African precipitation. J. Climate, 12, 11651184 .

Diedhiou, A., S. Janicot, A. Viltard, P. de Felice, and H. Laurent, 1999: Easterly wave regimes and associated convection over West Africa and the tropical Atlantic: Results from NCEP/NCAR and ECMWF reanalyses. Climate Dyn., 15, 795-822.

,,--- , and,- 2001 : Composite patterns of easterly disturbances over West Africa and the tropical Atlantic: A climatology from the 1979-95 NCEP/NCAR reanalyses. Climate Dyn., 18, 241-253.

Diongue, A., J. P. Lafore, J. L. Redelsperger, and R. Roca, 2002: Numerical study of a Sahelian synoptic weather system: Initiation and mature stages of convection and its interactions with the large-scale dynamics. Quart. J. Roy. Meteor. Soc., 128, 1899-1927.

Duchon, C. E., 1979: Lanczos filtering in one and two dimensions. J. Appl. Meteor., 18, 1016-1022.

Ferranti, L., J. M. Slingo, T. N. Palmer, and B. J. Hoskins, 1999: The effect of land-surface feedbacks on the monsoon circulation. Quart. J. Roy. Meteor. Soc., 125, 1527-1550.

Flatau, M., P. J. Flatau, P. Phoebus, and P. P. Niiler, 1997: The feedback between equatorial convection and local radiative and evaporative processes: The implications for intraseasonal oscillations. J. Atmos. Sci., 54, 2373-2386.

Folland, C. K., T. N. Palmer, and D. Parker, 1986: Sahel rainfall and worldwide sea temperatures: 1901-85. Nature, 320, 602-606.

Gill, A. E., 1980: Some simple solutions for heat-induced tropical circulation. Quart. J. Roy. Meteor. Soc., 106, 447-462.

Goldenberg, S. B., and L. J. Shapiro, 1996: Physical mechanisms for the association of El Niño and West African rainfall with Atlantic major hurricane activity. J. Climate, 9, 1169-1187.

Grodsky, S. A., and J. A. Carton, 2001: Coupled land/atmosphere interactions in the West African monsoon. Geophys. Res. Lett., 28, 1503-1506.

Hall, J. D., A. J. Matthews, and D. J. Karoly, 2001: The modulation of tropical cyclone activity in the Australian region by the Madden-Julian oscillation. Mon. Wea. Rev., 129, 2970-2982.

Hendon, H. H., 2000: Impact of air-sea coupling on the MaddenJulian oscillation in a general circulation model. J. Atmos. Sci., 57, 3939-3952.

, and M. L. Salby, 1994: The life cycle of the Madden-Julian oscillation. J. Atmos. Sci., 51, 2225-2237.

—_, B. Liebmann, M. Newman, J. D. Glick, and J. E. Schemm, 2000: Medium-range forecast errors associated with active episodes of the Madden-Julian oscillation. Mon. Wea. Rev., 128, 69-86.

Inness, P. M., and J. M. Slingo, 2003: Simulation of the MaddenJulian oscillation in a coupled general circulation model. Part I: Comparison with observations and an atmosphere-only GCM. J. Climate, 16, 345-364.

Janicot, S., and B. Sultan, 2001: Intra-seasonal modulation of con- 
vection in the West African monsoon. Geophys. Res. Lett., 28, 523-526.

_ A. Harzallah, B. Fontaine, and V. Moron, 1998: West African monsoon dynamics and eastern equatorial Atlantic and Pacific SST anomalies (1970-88). J. Climate, 11, 1874-1882.

-, S. Trzaska, and I. Poccard, 2001: Summer Sahel-ENSO teleconnection and decadal time scale SST variations. Climate Dyn. 18, 303-320.

Jones, C., D. E. Waliser, J. K. E. Schemm, and W. K. M. Lau, 2000: Prediction skill of the Madden and Julian Oscillation in dynamical extended range forecasts. Climate Dyn., 16, 272-289.

Kalnay, E., and Coauthors, 1996: The NCEP/NCAR 40-Year Reanalysis Project. Bull. Amer. Meteor. Soc., 77, 437-471.

Kemball-Cook, S. R., and B. Wang, 2001: Equatorial waves and airsea interaction in the Boreal summer intraseasonal oscillation. J. Climate, 14, 2923-2942.

Kiladis, G. N., and K. M. Weickmann, 1997: Horizontal structure and seasonality of large-scale circulations associated with submonthly tropical convection. Mon. Wea. Rev., 125, 1997-2013.

Knutson, D. R., and K. M. Weickmann, 1987: 30-60 day atmospheric oscillations: Composite life cycles of convection and circulation anomalies. Mon. Wea. Rev., 115, 1407-1436.

- - - , and J. E. Kutzbach, 1986: Global-scale intraseasonal oscillations of outgoing longwave radiation and $250 \mathrm{mb}$ zona wind during Northern Hemisphere summer. Mon. Wea. Rev., 114, 605-623.

Krishnamurti, T. N., and D. Subrahmanyam, 1982: The 30-50 day mode at $850 \mathrm{mb}$ during MONEX. J. Atmos. Sci., 39, 605-623.

Landsea, C. W., and W. M. Gray, 1992: The strong association between Western Sahel monsoon rainfall and intense Atlantic hurricanes. J. Climate, 5, 435-453.

Lawrence, D. M., and P. J. Webster, 2001: Interannual variations of the intraseasonal oscillation in the south Asian summer monsoon region. J. Climate, 14, 2910-2922.

_ Relationship between northward and eastward movement of convection. J. Atmos. Sci., 59, 1593-1606.

Le Barbé, L., and T. Lebel, 1997: Rainfall climatology of the HAPEXSahel region during the years 1950-1990. J. Hydrol., 189, 4373.

, -, and D. Tapsoba, 2002: Rainfall variability in West Africa during the years 1950-90. J. Climate, 15, 187-202.

Liebmann, B., and C. A. Smith, 1996: Description of a complete (interpolated) OLR dataset. Bull. Amer. Meteor. Soc., 77, 12751277.

Livezey, R. E., and W. Y. Chen, 1983: Statistical field significance and its determination by Monte Carlo techniques. Mon. Wea. Rev., 111, 46-59.

Lo, F., and H. H. Hendon, 2000: Empirical extended-range prediction of the Madden-Julian oscillation. Mon. Wea. Rev., 128, 25282543 .

Madden, R. A., and P. R. Julian, 1994: Observations of the 40-50 day tropical oscillation-A review. Mon. Wea. Rev., 122, 814 837.

Maloney, E. D., and D. L. Hartmann, 2000: Modulation of hurricane activity in the Gulf of Mexico by the Madden-Julian oscillation. Science, 287, 2002-2004.

_ tropical eastern Pacific during Northern Hemisphere summer. $J$. Climate, 15, 675-689.

Matthews, A. J., 2000: Propagation mechanisms for the MaddenJulian oscillation. Quart. J. Roy. Meteor. Soc., 126, 2637-2652.

- and G. N. Kiladis, 1999: The tropical-extratropical interaction between high-frequency transients and the Madden-Julian oscillation. Mon. Wea. Rev., 127, 661-677.

Meehl, G. A., R. Lukas, G. N. Kiladis, K. M. Weickmann, A. J. Matthews, and M. Wheeler, 2001: A conceptual framework for time and space scale interactions in the climate system. Climate Dyn., 17, 753-775.

Milliff, R. F., and R. A. Madden, 1996: The existence and vertical structure of fast, eastward-moving disturbances in the equatorial troposphere. J. Atmos. Sci., 53, 586-597.

Mo, K. C., 2001: Adaptive filtering and prediction of intraseasonal oscillations. Mon. Wea. Rev., 129, 802-817.

Murakami, T., L.-X. Chen, A. Xie, and M. L. Shresha, 1986: Eastward propagation of 30-60 day perturbations as revealed from outgoing longwave radiation data. J. Atmos. Sci., 43, 961-971.

North, G. R., T. L. Bell, R. F. Cahalan, and F. J. Moeng, 1982: Sampling errors in the estimation of empirical orthogonal functions. Mon. Wea. Rev., 110, 699-706.

Redelsperger, J. L., A. Diongue, A. Diedhiou, J. P. Ceron, M. Diop, J. F. Gueremy, and J. P. Lafore, 2002: Multi-scale description of a Sahelian synoptic weather system representative of the West African monsoon. Quart. J. Roy. Meteor. Soc., 128, 1229-1257.

Reed, R. J., J. C. Norquist, and E. E. Recker, 1977: The structure and properties of African wave disturbances as observed during phase III of GATE. Mon. Wea. Rev., 105, 317-333.

Reynolds, R. W., and T. M. Smith, 1994: Improved global sea surface temperature analyses using optimum interpolation. J. Climate, 7, 929-948.

Rowell, D. P., 2001: Teleconnections between the tropical Pacific and the Sahel. Quart. J. Roy. Meteor. Soc., 127, 1683-1706.

_ 2 2003: The impact of Mediterranean SSTs on the Sahelian rainfall season. J. Climate, 16, 849-862.

— C. K. Folland, K. Maskell, and M. N. Ward, 1995: Variability of summer rainfall over tropical North Africa (1906-1992): Observations and modelling. Quart. J. Roy. Meteor. Soc., 121, 669704.

Rui, H., and B. Wang, 1990: Development characteristics and dynamic structure of tropical intraseasonal convective anomalies. J. Atmos. Sci., 47, 357-379.

Sengupta, D., B. N. Goswami, and R. Senan, 2001: Coherent intraseasonal oscillations of ocean and atmosphere during the Asian summer monsoon. Geophys. Res. Lett., 28, 4127-4130.

Shinoda, T., and H. H. Hendon, 2001: Upper-ocean heat budget in response to the Madden-Julian oscillation in the western equatorial Pacific. J. Climate, 14, 4147-4165.

Slingo, J. M., and Coauthors, 1996: Intraseasonal oscillations in 15 atmospheric general circulation models: Results from an AMIP diagnostic subproject. Climate Dyn., 12, 325-358.

Spencer, R. W., J. R. Christy, and N. C. Grody, 1990: Global atmospheric temperature monitoring with satellite microwave measurements: Methods and results 1979-84. J. Climate, 3, 1111-1128

Sperber, K. R., J. M. Slingo, and H. Annamalai, 2000: Predictability and the relationship between subseasonal and interannual variability during the Asian summer monsoon. Quart. J. Roy. Meteor. Soc., 126, 2545-2574.

Sultan, B., and S. Janicot, 2000: Abrupt shift of the ITCZ over West Africa and intraseasonal variability. Geophys. Res. Lett., 27, 3353-3356.

Thorncroft, C. D., 1995: An idealised study of African easterly waves. 3. More realistic basic states. Quart. J. Roy. Meteor. Soc., 121, 1589-1614.

_ , and B. J. Hoskins, 1994a: An idealised study of African easterly waves. 1. A linear view. Quart. J. Roy. Meteor. Soc., 120, $953-$ 982

- , and _ - 1994b: An idealised study of African easterly waves. 2. A nonlinear view. Quart. J. Roy. Meteor. Soc., 120, $983-$ 1015 .

_ and D. P. Rowell, 1998: Interannual variability of African wave activity in a general circulation model. Int. J. Climatol., 18, 1305-1323.

_- and M. Blackburn, 1999: Maintenance of the African easterly jet. Quart. J. Roy. Meteor. Soc., 125, 763-786.

, and K. Hodges, 2001: African easterly wave variability and its relationship to Atlantic tropical cyclone activity. J. Climate, 14, 1166-1179.

- and Coauthors, 2003: The JET2000 project: Aircraft obser- 
vations of the African easterly jet and African easterly waves. Bull. Amer. Meteor. Soc., 84, 337-351.

Waliser, D. E., C. Jones, J.-K. E. Schemm, and N. E. Graham, 1999: A statistical extended-range tropical forecast model based on the slow evolution of the Madden-Julian oscillation. J. Climate, 12, $1918-1939$.

Wheeler, M., and K. M. Weickmann, 2001: Real-time monitoring and prediction of modes of coherent synoptic to intraseasonal tropical variability. Mon. Wea. Rev., 129, 2677-2694.

Woolnough, S. J., J. M. Slingo, and B. J. Hoskins, 2000: The relationship between convection and sea surface temperature on intraseasonal timescales. J. Climate, 13, 2086-2104.

Yasunari, T., 1981: Structure of an Indian summer monsoon system with around 40-day period. J. Meteor. Soc. Japan, 59, 336-354. 